\title{
ROLA GOPR W SYSTEMIE GRUP DYSPOZYCYJNYCH W PROCESIE ZAPOBIEGANIA ZAGROŻENIOM W REGIONACH TRANSGRANICZNYCH
}

\author{
THE ROLE OF THE MOUNTAIN RESCUE SYSTEM \\ DISPOSITIONAL GROUPS IN THE PREVENTION \\ OF RISKS IN CROSS-BORDER REGIONS
}

Jadwiga Mazur*, Tadeusz Michalczyk**

\begin{abstract}
- ABSTRAKT
Celem niniejszej analizy jest wskazanie roli, jaką w systemie zapobiegania zagrożeniom na terenach transgranicznych odgrywa Górskie Ochotnicze Pogotowie Ratunkowe. Kolejno zostaną omówione Górskie Ochotnicze Pogotowie Ratunkowe, jego miejsce wśród grup dyspozycyjnych i strategii bezpieczeństwa państwa oraz rola w procesie zapobiegania zagrożeniom w regionach transgranicznych.
\end{abstract}

Słowa kluczowe: grupy dyspozycyjne, regiony transgraniczne, współpraca, zapobieganie
The purpose of this analysis is to identify the role that Mountain Volunteer Ambulance Service plays in the system of risk prevention in the areas of cross-border. The discussion concerns mainly the Mountain Volunteer Ambulance Service, its place among groups of disposable and security policy of the state and a role in the prevention of risks in cross-border regions.

Keywords: dispositional group, cross-border regions, cooperation

* Uniwersytet Pedagogiczny im. KEN Kraków, Instytut Filozofii i Socjologii.

** Krakowska Akademia im. A. Frycza Modrzewskiego w Krakowie, Wydział Nauk o Bezpieczeństwie. 


\section{WPROWADZENIE}

Celem artykułu jest wskazanie znaczącej, chociaż niedocenionej w pełni, roli, jaką w systemie zapobiegania zagrożeniom na terenach transgranicznych odgrywa Górskie Ochotnicze Pogotowie Ratunkowe. System zarządzania kryzysowego jest strukturą złożoną, którą wypełniają grupy dyspozycyjne działające zgodnie z obowiązującym prawem. Przyjmuje się założenie, że system jest zdolny do reakcji w przypadku sytuacji kryzysowych, a także w obszarze zapobiegania zagrożeniom na terenach przygranicznych, a jego poszczególne części, zwłaszcza cywilne grypy dyspozycyjne związane z wolontariatem, mogą również wpływać pozytywnie na więzi społeczne. System ten stanowi jednocześnie integralną część systemu obronności RP. Artykuł ma charakter wprowadzenia do szerszego opracowania, które jest w przygotowaniu, dotyczącego funkcjonowania GOPR w systemie bezpieczeństwa państwa. Jednocześnie jest próbą zwrócenia uwagi na wolonatriackie grupy dyspozycyjne, które mogą się stać ważnym i bardziej docenianym elementem zintegrowanego systemu bezpieczeństwa państwa oraz zapobieganiu zagrożeniom.

Warto w tym miejscu nadmienić, że niewiele jest opracowań dotyczących GOPR, mają one w głównej mierze charakter wspomnieniowy, opisowy, zawierają sprawozdawczość z działalności. Pierwszym polskim autorem piszącym na temat ratownictwa w górskiego był inicjator i twórca TOPR, Mariusz Zaruski, który w wielu artykułach i notatkach, publikowanych w latach 1908-1913 na łamach Zakopanego, Taternika oraz Pamiętnika Towarzystwa Tatrzańskiego, wskazywał na potrzebę powołania pogotowia ratunkowego dla gór.W okresie międzywojennym publikował Ignacy Bujak, zamieszczał sprawozdania z działalności TOPR w kolejnych rocznikach Wierchów od 1927 r. do roku 1938, a jego działalność sprawozdawczą kontynuowali Tadeusz A. Pawłowski, Michał Jagiełło i Krystyna Sałyga [-Dąbkowska], natomiast od końca lat 80. Adam Marasek. Działalność ratownicza był omawiane szerzej na łamach Taternika przez Michała Jagiełłę, Eugeniusza Strzebońskiego, Andrzeja Paczkowskiego, Piotra Malinowskiego oraz Krystynę Sałygę [-Dąbkowską]. Duże zasługi w popularyzacji prac ratownictwa górskiego ma Wawrzyniec Żuławski, który w swoich publikacjach, takich jak: Niebieski krzyż (Warszawa 1946), Sygnały ze skalnych ścian (Warszawa 1954), Tragedie tatrzańskie (Warszawa 1956), poruszał te kwestie. Należy również wspomnieć o ważnych pracach poświęconych ratownictwu górskiemu autorstwa Michała Jagieły: Czekać spokojnie. Idziemy! (Warszawa 1975), Wołanie w górach (Warszawa 1979 i wydania kolejne), Wypadki i akcje ratunkowe w Tatrach, Gałazka kosodrzewiny. Najdaw- 
niejsze wypadki tatrzańskie w piśmiennictwie polskim (Warszawa 1999, II wyd. 2000, III wyd. 2001). Ważnymi pracami zbiorowymi poświęconymi ratownictwu górskiemu są również 50 lat ratownictwa górskiego. Zarys historii i działalności Górskiego Ochotniczego Pogotowia Ratunkowego (Zakopane 1959) z tekstami Walerego Goetla, Tadeusza Pawłowskiego, Jerzego Hajdukiewicza i Jana Alfreda Szczepańskiego. Następną pracą jest książka Sygnały z gór. Z dziejów minionych sześćdziesięciu lat działalności Górskiego Ochotniczego Pogotowia Ratunkowego PTTK (Warszawa 1973). Kolejną publikacją jest Błękitny krzyż, pod reakcją Stefana Maciejewskiego (Kraków 1981). Ważną podsumowującą pozycją jest praca „Na każde wezwanie...” pięćdziesiąt lat działalności Górskiego Ochotniczego Pogotowia Ratunkowego 1952-2002, pod red. Adama Jonaka (Kraków 2002), gdzie autorzy podjęli się opisu historii ratownictwa górskiego. Kolejną ważną pracą jest publikacja Piotra Millera Konstruowanie, tożsamości ratownika górskiego, Przegląd Socjologii Jakościowej ... monografie... 2010, Tom VI, Numer 1, w której opisuje on ważne kwestie działania w ratownictwie górskim. Inną ważną pracą autorstwa Kazimierza Mrozowicza jest Czynnik ludzki w górskim pogotowiu ratunkowym. Analiza osobowościowych uwarunkowań zachowań organizacyjnych ratowników górskich (Mrozowicz, 2013), w której podejmuje rozważania dotyczące psychospołecznych uwarunkowań zachowań organizacyjnych ratowników GOPR, z uwzględnieniem charakterystyki zachowań ratowniczych w obrębie odgrywanej przez nich roli społecznej. Obecnie tematyka gór, turystyki górskiej, historii i ratownictwa górskiego jest poruszana na łamach kwartalników turystycznych W górach czy Wierchy, Ratownik górski GOPR, prowadzonych z dużą starannością i mających swoje wydania internetowe, co znacznie rozszerza krąg czytelników.

\section{GRUPY DYSPOZYCYJNE I ICH ROLA W SYSTEMIE BEZPIECZEŃSTWA}

Grupy dyspozycyjne są definiowane jako „kategorie osób, które czerpią środki swej egzystencji z przygotowania do ochrony i bezpośredniego sprawowania ochrony dóbr ważnych dla całego systemu społecznego i poszczególnych osób przez posługiwanie się lub zagrożeniem posłużenia się w imieniu państwa środkami przymusu fizycznego lub przez bezpośrednie oddziaływanie bodźcami"(Morawski, 1999, s. 18).

Natomiast J. Maciejewski stwierdza, że „grupy dyspozycyjne są takimi zespolonymi w sposób rozmyślny strukturami społecznymi, o których dyspozycyjności 
możemy mówić w wąskim znaczeniu ze względu na ich wyspecjalizowany i specyficzny charakter działań w stosunkowo ograniczonym zakresie (Maciejewski, 2014, s. 54). Podkreśla, że grupy dyspozycyjne są usytuowane „w strukturze społecznej, podlegają transformacjom na makro-, mezo- i mikropoziomie. Praktyczny wymiar tych przemian przejawia się w procesach transformacyjnych" (Maciejewski, 2010, s. 11).

Dyspozycyjność ogólnie definiowana jest z kolei jako „gotowość dostosowania się do czyjejś dyspozycji. Zawiera aspekt poddania się woli nadrzędnego decydenta bądź ogólnemu rozwojowi sytuacji, a także aspekt potencji i niepewności" (Jarmoszko, 2006, s. 35.). Omawiając dyspozycyjność, należy odnieść się do różnych kategorii dyspozycyjności, związanych z posiadanymi uprawnieniami lub przygotowaniem i gotowością do podejmowania czynności i specjalistycznych zadań. Najczęściej są to aktywności wyspecjalizowane, związane z zabezpieczaniem różnych obszarów życia zbiorowego czy jednostkowego w sytuacji niebezpieczeństwa lub realnego już zagrożenia.

Dyspozycyjność formacji uzbrojonych i mundurowych odnosi się głównie do reprezentowania interesów państwa i obywateli zgodnie z prawem i dla jego bezpieczeństwa. Ich role, cele, funkcje i zadania, jakie wykonują w systemie bezpieczeństwa państwa, są jasno określone. Natomiast formacje nieuzbrojone znajdują swoje miejsce w obszarze działań o charakterze ochronnym. Jak wskazuje dokument Strategii Bezpieczeństwa Narodowego Rzeczypospolitej Polskiej z roku 2014 w pkt 88 „podstawowym zadaniem ochronnym są działania związane z ratowaniem życia, zdrowia, mienia i środowiska przed klęskami żywiołowymi lub spowodowanymi działalnością człowieka oraz innymi miejscowymi zagrożeniami. Wiodącą rolę w tym zakresie odgrywa Państwowe Ratownictwo Medyczne oraz Państwowa Straż Pożarna [...]. Ważnym wsparciem w tym zakresie jest współpraca ze wszystkimi służbami i podmiotami ratowniczymi, uwzględniająca również podmioty niezaliczone do sektora finansów publicznych (w tym organizacje pozarządowe, takie jak ochotnicze straże pożarne, podmioty uprawnione do ratownictwa górskiego i wodnego), a ustawowo uprawnione do realizowania działań z zakresu ratownictwa w Polsce"(Strategia Bezpieczeństwa Narodowego RP, 2014).

Zapis ten wskazuje na wagę udziału cywilnych wolontariackich grup dyspozycyjnych w strategii obrony kraju, ich rolę i zadania, jakie mają do wykonania, oraz daje możliwość wykorzystania ich specjalistycznych zasobów, w tym przede wszystkim kapitału ludzkiego i specjalistycznego sprzętu.

W typologii grup dyspozycyjnych i ich systematyzacji zaproponowanych przez J. Maciejewskiego, gdzie jako główne wymienia grupy dyspozycyjne 
militarne, paramilitarne i cywilne - cywilne wolontariackie znajdują szczególne miejsce (Maciejewski, 2014, s. 66). W cywilnych grupach dyspozycyjnych wymienia dwa typy: jedne funkcjonują $\mathrm{w}$ administracyjnej strukturze państwa, a drugie jako specjalistyczne grupy w strukturach samorządowych, mogące mieć również charakter dobrowolnych zrzeszeń. Ochotnicze grupy dyspozycyjne, nazywane przez J. Maciejewskiego również wolontariackimi grupami ratunkowymi, skupiają osoby realizujące swoje zainteresowania i pasję, dzięki którym w znaczącym stopniu jest wspomagany system ratownictwa. To cenne działania, przydatne i ważne w sytuacji zagrożeń, katastrof, ale także w warunkach, kiedy potrzebne jest współdziałania do organizowania bezpiecznej przestrzeni. Tym bardziej że osoby zaangażowane w działanie ochotniczych grup dyspozycyjnych posiadają wiedzę, doświadczenia, a w wielu przypadkach specjalistyczne uprawnienia, nierzadko również sprzęt do niesienia pomocy ratowniczej. Ponadto ważnym aspektem jest, to, że w skład tych grup w dużej mierze wchodzą członkowie lokalnej społeczności, rozpoznawalni przez nią i obdarzani zaufaniem. Grupy te cieszą się zaufaniem społecznym, co w sytuacji akcji ratowniczych ułatwia im pozyskanie dodatkowej pomocy ze strony lokalnej społeczności.

Kierując się tą typologią i wątkiem społecznego podziału pracy, można stwierdzić, że wymienione w tytule artykułu Górskie Ochotnicze Pogotowie Ratunkowe jest cywilną, ochotniczą grupą dyspozycyjną, usytuowaną w strukturach samorządowych, jej działanie jest regulowane za pomocą odrębnych przepisów i pełni ważną funkcję w społecznej przestrzeni, niosąc wyspecjalizowaną pomoc w zakresie ratownictwa na terenach górskich oraz pełnią funkcje związane z zapobieganiem zagrożeniom. Ponadto członkowie zespołu posiadają specjalistyczną wiedzę i umiejętności, doświadczenie w obszarze ratownictwa. Należy nadmienić, że jest to grupa, a nawet bardziej zespół zadaniowy, gotowa do szybkich i doraźnych działań, niosąca wyspecjalizowaną pomoc.

\section{GOPR W SYSTEMIE GRUP DYSPOZYCYJNYCH}

Wzrost zagrożeń i ich zmienność oraz wielorakość we współczesnym świecie powodują potrzebę przeciwdziałania. Powołane do tego systemy za swoje główne zadanie przyjmują ratownictwo w sytuacjach kryzysowych, usuwanie skutków katastrof, przeciwdziałanie wydarzeniom, których sprawcą może być tak człowiek, jak i siły natury. 
Naturalną odpowiedzią na wzrost zagrożeń, jak podkreśla J. Maciejewski, staje się specjalizacja również w cywilnych grupach dyspozycyjnych, a ich kryterium podziału wynika „z terenu działań i niezbędnego wyposażenia w sprzęt ratowniczy, do którego obsługi potrzebna jest specjalistyczna wiedza oraz ciągłe szkolenie w posługiwaniu się nim" (Maciejewski, 2014, s. 72). Następnie - uszczegóławiając określenie przedmiotu badań socjologii grup dyspozycyjnych - wskazuje na określenie różnic między grupami dyspozycyjnymi w obrębie systemów militarnych, paramilitarnych i cywilnych, wymieniając w tych ostatnich te, które funkcjonują w agendach państwowych jak np. Straż Pożarna, czy w strukturach samorządowych, jak np. Tatrzańskie Górskie Pogotowie Ratunkowe (Maciejewski, 2014, s. 57).

Górskie Ochotnicze Pogotowie Ratunkowe jest jedną z organizacji wymienianych w Strategii Bezpieczeństwa Państwa, w części dotyczących działań ochronnych. GOPR jest polską organizacją powstałą w Zakopanem w 1952 roku, prowadzącą działania o charakterze ratowniczym, zapobiegającym wypadkom w górach oraz przygotowaną do szkoleń w tym zakresie. W jej strukturach działa też TOPR (Tatrzańskie Ochotnicze Pogotowie Ratunkowe). Zarówno GOPR, jak i TOPR są organizacjami o charakterze zamkniętym. Ratownicy tych organizacji przechodzą intensywne szkolenia i posiadają umiejętności teoretyczne oraz praktyczne, dobrą sprawność fizyczną i kondycję psychofizyczną, wiedzę medyczną, wiedzę z zakresu topografii terenu, umiejętność jazdy na nartach itp. Korzystają z nowoczesnego sprzętu ratowniczego, chociaż potrzeba dalszego ich doinwestowania jest konieczna oraz niezbędna dla sprawnego funkcjonowania w systemie ratownictwa i dla możliwości podawania stałej, realnej pomocy poszkodowanym. To organizacja budząca zaufanie i wielokrotnie podziw dla rzadkich umiejętności i odwagi wykazywanej w ratowaniu innych z narażeniem własnego życia i zdrowia.

Ratownictwo górskie i narciarskie podlega MSW, a zadania w zakresie nadzoru nad ratownictwem górskim realizuje Minister Spraw Wewnętrznych na podstawie zapisów Ustawy o bezpieczeństwie i ratownictwie w górach i na zorganizowanych terenach narciarskich, która weszła w życie od początku 2012 roku (Nadzór nad Ratownictwem Górskim $i$ Wodnym). Z ratownictwem górskim bezpośrednio łączy się ratownictwo narciarskie, które ma odrębne regulacje, o których warto wspomnieć przy opisie tej tematyki.

W myśl Ustawy z dnia 18 sierpnia 2011 roku o bezpieczeństwie i ratownictwie w górach i na zorganizowanych terenach narciarskich, która weszła w życie 31 grudnia 2011 roku, dokonano podziału na ratownictwo górskie i ratownictwo na zorganizowanych terenach narciarskich (ratownictwo narciarskie), określając 
legalne definicje tych pojęć. Zgodnie z ustawą ratownictwo narciarskie to podmioty odpowiedzialne za zapewnienie bezpieczeństwa osobom przebywającym na zorganizowanych terenach narciarskich. Odpowiedzialność za zapewnienie warunków bezpieczeństwa osobom przebywającym na zorganizowanych terenach narciarskich ustawodawca nałożył na osobę fizyczną, osobę prawną lub jednostkę organizacyjną nieposiadającą osobowości prawnej będącą właścicielem, użytkownikiem, najemcą, dzierżawcą lub posiadającą inny tytuł prawny do zorganizowanego terenu narciarskiego lub urządzeń transportu linowego lub taśmowego przeznaczonych do transportu osób, przy których znajduje się zorganizowany teren narciarski, to jest na zarządzającego zorganizowanym terenem narciarskim (art. 19 ust. 1 ustawy). Rozwiązuje to kwestie odpowiedzialności m.in. za bezpieczeństwo na trasach narciarskich.

Natomiast zapewnienie bezpieczeństwa polega w szczególności na: przygotowaniu, oznakowaniu, zabezpieczeniu terenów, obiektów i urządzeń służących do uprawiania narciarstwa i snowboardingu oraz bieżącej kontroli stanu zabezpieczeń, oznaczeń i warunków narciarskich; zapewnieniu ratownictwa narciarskiego; określeniu i upowszechnieniu zasad korzystania z danego terenu, obiektu i urządzenia; informowaniu o warunkach narciarskich i ich zmianach; prowadzeniu działalności profilaktycznej i informacyjnej dotyczącej bezpieczeństwa podczas uprawiania narciarstwa i snowboardingu. To również rozwiązania w zakresie przekazywaniu informacji i tworzeniu ułatwień szczególnie istotnych dla potrzeb osób z różnymi rodzajami niepełnosprawności, przebywającymi na zorganizowanych terenach narciarskich. Ustawa podaje też podmioty uprawnione do wykonywania ratownictwa na zorganizowanych terenach narciarskich i zakres ich obowiązków oraz zasady finansowania ratownictwa narciarskiego (Nadzór nad...).

Z kolei samo ratownictwo górskie ma odrębne rozwiązania prawne. W myśl przepisów podmiotami uprawnionymi do wykonywania ratownictwa górskiego (na postawie zgody Ministra Spraw Wewnętrznych na wykonywanie ratownictwa górskiego) są Górskie Ochotnicze Pogotowie Ratunkowe oraz Tatrzańskie Ochotnicze Pogotowie Ratunkowe.

Natomiast odpowiedzialność za bezpieczeństwo w górach ponoszą minister właściwy do spraw wewnętrznych, organy jednostek samorządu terytorialnego, na terenie których wykonywane jest ratownictwo górskie, dyrekcja parków narodowych i krajobrazowych położonych na obszarze gór, a także osoby fizyczne, osoby prawne oraz jednostki organizacyjne nieposiadające osobowości prawnej prowadzące w górach zorganizowaną działalność w zakresie sportu, rekreacji lub 
turystyki. Przepisy mają też wymiar praktyczny w wymiarze finansowym, np. co prawda niewielki, ale ważny procent części opłat pochodzących ze wstępów do parków narodowych przeznaczanych jest na ratownictwo górskie (GOPR).

Zgodnie $\mathrm{z}$ ustawą zapewnienie warunków bezpieczeństwa $\mathrm{w}$ górach polega w szczególności na: oznakowaniu terenów, obiektów i urządzeń służących do uprawiania sportu, rekreacji lub turystyki; ustaleniu zasad korzystania $\mathrm{z}$ danego terenu, obiektu lub urządzenia; zapewnieniu podmiotom uprawnionym do wykonywania ratownictwa górskiego warunków do organizowania pomocy oraz ratowania osób, które uległy wypadkowi lub są narażone na niebezpieczeństwo utraty życia lub zdrowia; ogłaszaniu komunikatu lawinowego.

Ustawa podaje, że ratownictwo mogą wykonywać GOPR, TOPR oraz inne podmioty, jeżeli uzyskały zgodę ministra właściwego do spraw wewnętrznych i stały się podmiotami uprawnionymi do wykonywania ratownictwa górskiego. W ramach ratownictwa górskiego są podejmowane działania ratownicze, polegające w szczególności na: przyjęciu zgłoszenia o wypadku lub innym zdarzeniu; dotarciu na miejsce wypadku z wyposażeniem ratowniczym; udzieleniu kwalifikowanej pierwszej pomocy; zabezpieczeniu i ewakuacji osób przebywających w górach z terenów stanowiących zagrożenie dla życia i zdrowia; transporcie osób, które uległy wypadkowi lub są narażone na niebezpieczeństwo utraty życia lub zdrowia do miejsca, gdzie jest możliwe podjęcie medycznych czynności ratunkowych przez jednostki systemu Państwowego Ratownictwa Medycznego.

Zadania $\mathrm{z}$ zakresu ratownictwa górskiego powierzane i finansowane są przez ministra właściwego do spraw wewnętrznych oraz przez jednostki samorządu terytorialnego w ramach dotacji celowych (Nadzór nad...). Dotacje mogą być udzielane z pominięciem otwartego konkursu ofert i mogą być udzielone na: utrzymanie gotowości ratowniczej; prowadzenie działań ratowniczych; organizowanie i prowadzenie szkoleń ratowników górskich oraz psów ratowniczych, w tym psów lawinowych; opracowywanie i udostępnianie komunikatu lawinowego; utrzymanie śmigłowca ratowniczego wraz z załogą lotniczo-techniczną będącego w dyspozycji podmiotu uprawnionego do wykonywania ratownictwa górskiego, przeznaczonego w szczególności do działań ratownictwa górskiego w Tatrach oraz na terenie południowej Małopolski; prowadzenie dokumentacji wypadków (Nadzór nad...). Rozwiązania w tym zakresie są jasne i klarowne, niemniej nie rozwiązują w sposób zadowalający kwestii dofinansowania tych służb, niezbędnych przy podejmowaniu ratownictwa życia i zdrowia osób narażonych na niebezpieczeństwo w górach. Tym bardziej że osoby korzystające z różnych form ratownictwa nie ponoszą jego kosztów, a utrzymanie tych służb wymaga 
nakładów finansowych. Ustawa reguluje również obowiązki osób przebywających w górach, nakładając na nie obowiązek do zachowania należytej staranności w celu ochrony życia i zdrowia własnego oraz innych osób (Nadzór nad...).

Zadania i wyzwania spoczywające na GOPR i TOPR, nałożone na nie przez ustawodawcę, są duże i wymagają określonego finansowania. Ze względu na cel artykułu i jego obszerność nie jest zasadne przytaczanie konkretnych sum, jakimi dysponowały te podmioty, ale warto na nie spojrzeć (Komórki organizacyjne Ministerstwa wspótpracujace $z$ organizacjami pozarządowymi) i porównać ich szczupłość $\mathrm{z}$ wielością oraz znaczeniem realizacji celów i zadań. Warto również docenić $\mathrm{z}$ tej perspektywy wagę tych podmiotów w systemie zarządzania kryzysowego i obronności RP.

Warto w tym miejscu zaznaczyć, że badania w tych grupach mają swoją specyfikę, ze względu na dostęp do informacji ograniczony klauzulami poufności lub tajności. Stąd zazwyczaj sfera jawna jest w zasadzie dostępna, natomiast dostęp do informacji niejawnych jest reglamentowany. Z tego wynika pewna trudność w badaniu grup dyspozycyjnych i pojawia się nam w sposób naturalny tzw. trudny respondent (Mazur, 2014, s. 315). W nieco mniejszym stopniu dotyczy to GOPR, TOPR i WOPR, niemniej badania w tych grupach również wymagają sporego nakładu czasowego i zaangażowania ze strony osób badających. Tym bardziej że jest to teren badawczy mało opisany, a ze względu na swoją wagę, specyfikę i rolę w strategii bezpieczeństwa państwa bardzo ważny.

Warto w tym miejscu nadmienić, że GOPR jest ważnym, chociaż nie w pełni docenianym podmiotem, wymienianym nie tylko w systemie grup dyspozycyjnych, ale także w systemie zarządzania kryzysowego. W definicjach zarządzania podkreśla się traktowanie tegoż zarządzania jako procesu, wymieniając przy tym jego cykle i fazy, jak np.: planowania, reagowania oraz odbudowy. Zakończenie sytuacji kryzysowej jest związane z przygotowaniem się do reakcji na kolejną, do której włączyć można nie tylko odtwarzanie zniszczeń fizycznych, ale także edukację do bezpieczeństwa, prowadzoną często równolegle $\mathrm{z}$ fazą zapobiegania.

Zapisy ustawy, która definiuje zarządzanie kryzysowe jako „działalność organów administracji publicznej będącą elementem kierowania bezpieczeństwem narodowym i która polega na zapobieganiu sytuacjom kryzysowym, przygotowaniu do przejmowania nad nimi kontroli w drodze zaplanowanych działań, reagowaniu w przypadku wystąpienia sytuacji kryzysowych, usuwaniu ich skutków oraz odtwarzaniu zasobów i infrastruktury krytycznej” (Ustawa o zarządzaniu kryzysowym), wskazują na niezbędność udziału wolonatriackich 
grup dyspozycyjnych. Znaczenie tych grup podkreślono również w Strategii Bezpieczeństwa RP z roku 2014. Stąd istnieje nie tylko potrzeba ich dogłębnego badania i opisu, ale i wskazania na wagę roli, jaką pełnią w systemie bezpieczeństwa państwa zarówno w stanie wojny, jak i pokoju. Tym bardziej że opracowań dotyczących GOPR jest niewiele i wymagają uzupełnienia, zarówno ze strony nauk o zrządzaniu, socjologii, psychologii, jak i nauk o bezpieczeństwie.

GOPR jest organizacją mocowaną w opisie grup dyspozycyjnych w grupie wolontariackich cywilnych grup dyspozycyjnych. Organizacje pozarządowe, w grupie których możemy lokować GOPR, definiuje się zwykle jako podmioty, których działanie nie jest nastawione na zysk i nie stanowią elementu aparatu państwowego. Wymieniane są jako „organizacje społeczne, obywatelskie, pozarządowe, non governmental organization - NGO, niedochodowe, non profit - NPO, użyteczności społecznej, charytatywne, pomocowe, woluntarystyczne, niezależne itp."(Schmidt, 2012, s. 14). Funkcjonowanie tych organizacji gwarantuje Konstytucja RP w art. 12 (zapewnia wolność tworzenia i działania związków zawodowych, organizacji społeczno-zawodowych rolników, stowarzyszeń, ruchów obywatelskich, innych dobrowolnych zrzeszeń oraz fundacji, a w art. 58 w ust. 1 - Każdemu zapewnia się wolność zrzeszania się).

Z kolei Ustawa z 7 kwietnia 1989 r. - prawo o stowarzyszeniach - podaje, że stowarzyszenie jest dobrowolnym, samorządnym, trwałym zrzeszeniem o celach niezarobkowych; wyróżnia też kategorię organizacji pożytku publicznego (OPP). W informacji zawartej na stronie departamentu Pożytku Publicznego można przeczytać „stosownie do przepisów uchwalonej w dniu 24 kwietnia 2003 r. ustawy o działalności pożytku publicznego i o wolontariacie (Dz. U. Nr 96, poz. 873) oraz przepisy wprowadzające ustawę o działalności pożytku publicznego i o wolontariacie (Dz. U. Nr 96, poz. 874) organizacje pozarządowe oraz inne podmioty prowadzące działalność pożytku publicznego mogą od dnia 1 stycznia 2004 r. uzyskiwać szczególny status organizacji pożytku publicznego. Ze statusem tym związane są szczególne uprawnienia, ale też i obowiązki takich organizacji. Głównym celem ich utworzenia było stworzenie pewnej elity wśród podmiotów zaliczanych do trzeciego sektora. Elity prowadzącej działalność społecznie użyteczną na rzecz ogółu społeczności, której cechą charakterystyczną jest transparentność zarówno w momencie rejestracji, jak i w całym okresie działania” (Organizacje posiadające status OPP).

O status organizacji pożytku publicznego mogą ubiegać się również „organizacje prowadzące działalność w zakresie ratownictwa i ochrony ludności oraz pomocy ofiarom katastrof, klęsk żywiołowych, konfliktów zbrojnych i wojen 
w kraju i za granicą" (Organizacje posiadające...). GOPR można więc z powodzeniem, ze względu na prowadzoną działalność i jej charakter, umieścić również w grupie Organizacji Pożytku Publicznego.

\section{GOPR W NOWEJ STRATEGII OBRONNOŚCI RP}

W Strategii Bezpieczeństwa Narodowego Rzeczypospolitej Polskiej z 2014 GOPR - jako wolontariacka cywilna grupa dyspozycyjna - pełni ważną rolę w działaniach ochronnych. Autorzy tej strategii wskazują na potrzebę optymalnego wykorzystania na potrzeby bezpieczeństwa wszystkich zasobów pozostających w dyspozycji państwa w sferze obronnej, ochronnej, społecznej i gospodarczej. W strategii określony został potencjał bezpieczeństwa narodowego oraz ocena środowiska bezpieczeństwa Polski w wymiarze globalnym, regionalnym i krajowym, a także prognozy i ich trendy rozwojowe. Przedstawione zostały działania państwa konieczne do osiągnięcia zdefiniowanych interesów i celów oraz kierunki oraz sposoby przygotowania systemu bezpieczeństwa narodowego (Strategia Bezpieczeństwa Narodowego...).

W Strategii zostały wymienione cele strategiczne w dziedzinie bezpieczeństwa powszechnego, a w nich „doskonalenie krajowego systemu ratowniczo-gaśniczego oraz systemu monitorowania, powiadamiania, ostrzegania o zagrożeniach i likwidowania skutków klęsk żywiołowych oraz katastrof (...), doskonalenie i rozwój krajowego systemu zarządzania kryzysowego w kierunku zapewnienia jego wewnętrznej spójności i integralności (...), pogłębianie świadomości społecznej w sferze bezpieczeństwa oraz zwiększanie kompetencji obywateli pozwalających na właściwe reagowanie w sytuacjach kryzysowych" (Strategia Bezpieczeństwa Narodowego...).

Następnie wskazuje się na potrzebę koordynacji działań z uwzględnieniem cywilnych grup dyspozycyjnych, w tym organizacji pozarządowych, a zwłaszcza wskazuje się na społeczne organizacje ratownicze (Strategia Bezpieczeństwa Narodowego...). Ze względu na ich kapitał zarówno ludzki, techniczny, jak i intelektualny, włącza się je w system obronny, który może być dobrym zapleczem pomocowym dla militarnych i paramilitarnych grup dyspozycyjnych. Dobrym przykładem tego typu jest Górskie Ochotnicze Pogotowie Ratunkowe, które ze względu na jego aspekt ochotniczy i wysokie kwalifikacje ratowników jest znaczącym elementem systemu działającego w sytuacjach kryzysowych. Ponadto 
ich dodatkowym atrybutem jest duży potencjał edukacyjny i kapitał zaufania, jakimi obdarzane są GOPR i TOPR, co zwiększa ich możliwości uzyskiwania dodatkowej pomocy ze strony lokalnych społeczności w sytuacjach kryzysowych.

O wadze ochotniczych cywilnych grup dyspozycyjnych świadczy zapis w rozdziale III Strategii, opisujący Koncepcje działań strategicznych, strategie operacyjną, gdzie w punkcie 88 , wskazuje się na potrzebę zapewnienia bezpieczeństwa powszechnego (w tym ratownictwa i ochrony ludności). Przewodnią rolę w tym obszarze stanowi Państwowe Ratownictwo Medyczne, Państwowa Straż Pożarna, a „ważnym wsparciem jest współpraca ze wszystkimi służbami i podmiotami ratowniczymi, uwzględniająca również podmioty niezaliczone do sektora finansów publicznych (w tym organizacje pozarządowe, takie jak ochotnicze straże pożarne, podmioty uprawnione do ratownictwa górskiego i wodnego), a ustawowo uprawnione do realizowania działań z zakresu ratownictwa w Polsce" (Strategia Bezpieczeństwa Narodowego...). Organizacje te, wchodzące w system ochotniczych cywilnych grup dyspozycyjnych, włączone w system działań ochronnych, stają się znaczącymi podmiotami w strategii bezpieczeństwa państwa. Ważne są w tej sytuacji również współpraca i sprawne komunikowanie się tych podmiotów, pozwalające na pełne wykorzystanie posiadanych zasobów.

Ważną przesłanką jest zharmonizowanie wszelkich działań oraz dbałość realizatorów w przygotowaniu podsystemów wsparcia, w których mieszczą się działania ochotniczych cywilnych grup dyspozycyjnych. Przedsięwzięcia te wymagają spójności w zarządzaniu kryzysowym, dopracowania wspólnych obszarów i planów zarządzania kryzysowego oraz operacyjnego wszelkich szczebli i dostosowania ich do działań.

Strategia Bezpieczeństwa Narodowego jest odzwierciedleniem głównych założeń operacyjnych i preparacyjnych, która przewiduje również w swoich wątkach doskonalenie standardów w obszarze ratowniczym i uwzględnienie domen współpracy poszczególnych podmiotów, w tym ochotniczych cywilnych grup dyspozycyjnych, w obszarze których umocowane jest działanie GOPR.

GOPR i TOPR we wszystkich tych sferach pełnią rolę znaczącą, ale mało jeszcze docenianą i opisaną. Stąd istnieje istotna potrzeba objęcia badaniami cywilnych grup wolontariackich, których wyniki mogłyby być ważnym elementem nie tylko oceny ich działania, ale przede wszystkim możliwości wykorzystania ich potencjału w systemie obronności kraju oraz w sytuacjach kryzysowych. 


\section{GOPR JAKO UCZESTNIK W PROCESIE ZAPOBIEGANIA ZAGROŻENIOM W REGIONACH TRANSGRANICZNYCH}

Chcąc mówić o GOPR w procesie zapobiegania zagrożeniom we współpracy transgranicznej, należy w pierwszej kolejności przybliżyć problematykę euroregionów, ponieważ jest to formalna struktura współpracy transgranicznej. W tym kontekście szczegółowiej należałoby przedstawić problematykę euroregionów.

Euroregion w literaturze przedmiotu to „formalna struktura współpracy transgranicznej skupiająca przedstawicieli szczebla lokalnego i regionalnego, a także w uzasadnionych przypadkach partnerów społecznych. Są to podmioty prawne, które stawiają przed sobą cele i posiadają rozległe możliwości działania" (Euroregiony w Polsce). Obszarami współpracy euroregionalnej są tereny przygraniczne (graniczne, nadgraniczne); obszar i strefa, obszar pograniczny, pogranicze, obszar transgraniczny, region, region przygraniczny (graniczny, nadgraniczny), region transgraniczny, euroregion. Z kolei obszar pograniczny, pogranicze i obszar transgraniczny są pojęciami o zbliżonym zakresie znaczeniowym i rozumieć go można jako obszar położony w sąsiedztwie (pobliżu) granicy po obu jej stronach (Euroregiony...). Współpraca w tych regionach jest traktowana jako jeden $\mathrm{z}$ priorytetów UE.

Na pograniczu Polski euroregiony reprezentują w większości lokalny model współpracy, polegający na działaniu stowarzyszeń samorządowych po obu stronach granicy - są to związki celowe gmin. „Euroregion staje się zatem dobrowolnym zrzeszeniem stowarzyszeń skupiających lokalne jednostki samorządowe. Obejmuje swym obszarem gminy i powiaty będące członkami związków celowych, a więc działa na terytorium członków, sygnatariuszy porozumień" (Sanetra-Półgrabi, 2015, s. 10). Warunkiem uczestnictwa w strukturze euroregionu jest uzyskanie członkostwa w związku celowym gmin. Euroregiony nie mają osobowości prawnej, ale posiadają stowarzyszenia, mają też samorządowy model współpracy, co sprzyja podejmowaniu wspólnych działań. „Pod względem normatywnym są to zatem właściwe podmioty współpracy transgranicznej zrzeszające gminy czy powiaty i, co za tym idzie, społeczności lokalne wokół wspólnych wartości, celów i przekonań, a jednocześnie struktury odpowiedzialne za prowadzenie współpracy w rozmaitych dziedzinach" (Sanetra- Półgrabi, 2015, s. 10).

Struktury transgraniczne są zazwyczaj przykładem instytucji, a procesy instytucjonalizacji są obserwowalne $\mathrm{i} \mathrm{w}$ sytuacji powodzenia $\mathrm{w}$ realizacji wspólnych celów mogą być i są przykładem dobrych praktyk. Instytucjonalizacja 
definiowana jest w socjologii jako „proces przejścia od niesformalizowanych i nie uregulowanych sposobów zachowania do względnie stałych i społecznie usankcjonowanych form aktywności wewnątrz układu społecznego (grupy społecznej, społeczeństwa)" (Olechnicki, Załęcki, 1997, s. 85). Instytucje społeczne w węższym znaczeniu rozumie się jako „zorganizowany i utrwalony zespół działań ludzkich, zakładający istnienie zasady naczelnej (celu instytucji), personelu, norm, środków materialnych, funkcji i rzeczywistej działalności, nakierowanych na zaspokojenie określonych potrzeb; w szerszym znaczeniu - względnie trwały układ społecznie ustanowionych sposobów i reguł zachowania, usankcjonowanych przez normy społeczne...”(Olechnicki, Załęcki, 1997, s. 85). Natomiast termin instytucja w naukach o organizacji rozumiany jest jako sformalizowana organizacja, a w naukach prawnych jako zespół norm prawnych (Bankowicz, 1999, s. 88).

Realizacja zadań w euroregionie w dużej mierze zależy od stopnia profesjonalizacji instytucji, sposobów realizacji wyznaczonych celów i aktywności w realizacji wyznaczonych we współpracy transgranicznej zadań. Ponadto spoiwem wspólnych działań jest spory obszar wspólnych potrzeb i problemów, w tym w zakresie ratownictwa górskiego. Realizacji tych przedsięwzięć sprzyjają przyjęte rozwiązania, jak np. Stowarzyszenie Europejskich Regionów Granicznych (SERG), do zadań którego należy realizowanie wspólnych programów i projektów, wnioskowanie o środki finansowe, współudział w rozwiązywaniu problemów transgranicznych, wspieranie ważnych inicjatyw, przygotowanie i realizacja wspólnych akcji, rozbudowa centrum europejskich regionów granicznych i transgranicznych.

W czasie ostatnich kilkunastu lat na granicach Polski powstało 16 euroregionów, w tym siedem na granicy południowej, są to polsko-czeskie euroregiony Glacensis, Pradziad, Śląsk Cieszyński i Silesia, polsko-czesko-słowacki Euroregion Beskidy, polsko-słowacki Euroregion Tatry oraz położony na styku pogranicza wschodniego i południowego polsko-słowacko-ukraińsko-rumuńsko-węgierski Euroregion Karpacki. Wśród wielu zadań, dotyczących współpracy w różnych obszarach, jest również współpraca w rozwiązywaniu wspólnych problemów w dziedzinach transportu, komunikacji i łączności, bezpieczeństwa obywateli, rozwoju potencjału ludzkiego i podniesienia jakości życia mieszkańców euroregionu, wspierania konkretnych projektów i planów, będących przedmiotem wspólnego zainteresowania, identyfikowania potencjalnych obszarów wielostronnej współpracy pomiędzy członkami, pośredniczenia i ułatwiania współpracy członków z organizacjami, agencjami i instytucjami 
(Stan wspótpracy euroregionalnej...). W wymienionych zadaniach mieszczą się również rozwiązania dotyczące współpracy GOPR z innymi podmiotami w zakresie zapobiegania zagrożeniom związanymi z (chociażby) zagrożeniem lawinowym, bezpieczeństwem narciarzy (zwłaszcza poza rejonem wyznaczonych tras narciarskich) i turystów górskich.

W analizie współpracy wskazuje się na pojawiające się bariery dotyczące skomplikowanych procedur realizacji i rozliczania projektów, trudność w znalezieniu partnera zagranicznego, bariera językowa, zmiana zasad funkcjonowania programu w trakcie realizacji projektów, asymetrie potencjałów uczestników współpracy (Stan wspólpracy euroregionalnej...). Dotyczy to również działania i zapobiegania zagrożeniom ze strony GOPR, chociaż są podejmowane w ostatniej dekadzie kroki zmierzające do znacznej poprawy tej sytuacji.

We współpracy transgranicznej w euroregionach występują niebezpieczeństwa związane z zagrożeniem zdrowia, życia i mienia ze strony zarówno człowieka, jak i natury. Zagrożenia przeciwko zdrowiu, życiu i mieniu związane są głównie z przekroczeniem prawa. Natomiast te związane pośrednio lub bezpośrednio z naturą to zagrożenia, które wymagają działań ratowniczych ze strony służb ratowniczych, takich jak GOPR, TOPR. Do zagrożeń tych można zaliczyć również wszelkie ich formy związane z turystyką górską, narciarstwem, które wynikają raczej z nieostrożności i braku przestrzegania obowiązujących norm (niekoniecznie mających charakter naruszenia norm prawa). Znaczącą rolę w zapobieganiu drugiego typu zagrożeń, tj. niezwiązanych z przestępczością, ma GOPR ze względu na umiejętności, wiedzę, doświadczenie i posiadane wyposażenie specjalistyczne, nieocenione, biorąc pod uwagę teren pogranicza Polski, Słowacji i Czech, na którym prowadzi działania. Funkcje i zadania GOPR są zawarte w statucie i odnoszą się głównie do ratownictwa, które z powodzeniem można określić jako specjalistyczne.

Pierwsza i główna sfera tych działań odnosi się do ratownictwa górskiego i zadania w tej sferze są realizowane na bieżąco w zależności od potrzeb. W tym zakresie podejmowane są inicjatywy w pasie przygranicznym dotyczące współdziałania służb niosących pomoc w sytuacji zagrożenia życia i zdrowia, które są regulowane przepisami krajowymi, jak i poprzez porozumienia, umowy między Polską i Słowacją oraz Polską i Czechami. Jako przykład można podać deklarację podpisaną 1 lipca 2014 roku w Zakopanem - memorandum wzajemnej współpracy organizacji ratownictwa górskiego z Polski, Słowacji i Czech, którego celem jest bliższe współdziałanie w ramach szkoleń i ustalanie jednorodnych zasad prowadzenia wspólnych działań ratowniczych. Jednym z celów jest zbudowanie 
wspólnego systemu ratownictwa śmigłowcowego do poszukiwań i ratownictwa w górach oraz opracowywanie i wykorzystanie informacji o zagrożeniach lawinowych. Zadeklarowano również wzajemne wsparcie w kształceniu i szkoleniu oraz opracowywanie procedur działania i zasad wspólnych akcji ratowniczych (Ratownicy górscy Polski, Czech i Słowacju chca ścisłej współpracować). Takie działania dają możliwość niesienia aktywnej pomocy poszkodowanym. Mają charakter współpracy, a w niej wykorzystanie posiadanych aktywów po obu stronach granicy. Ponadto pozwalają na strategiczne planowanie przyszłych działań.

Należy tutaj nadmienić, że specyfika pogranicza Polski, Słowacji i Czech odnosi się głównie do ukształtowania terenu. Góry, jakkolwiek mające duże walory krajobrazowe i turystyczne, wymagają sporych nakładów związanych z bezpieczeństwem i pojawiającymi się tam zagrożeniami. Należą do nich zarówno lawiny, jak i zagrożenia związane z lekceważeniem przez turystów podstawowych zasad przebywania w górach. Pośrednio mogą być też (i są) związane z przestępczością transgraniczną, dotyczącą chociażby nielegalnej migracji, chociaż głównym celem jest tutaj ratowanie zdrowia i życia człowieka, bez względu na jego status prawny czy przekroczenie norm prawnych.

Kolejne zagrożenia związane są z uprawianymi sportami, typu narciarstwo, wspinaczka, czy zwykła turystyka górska. Obowiązki zabezpieczenia tras narciarskich i szlaków turystycznych oraz ich stałego utrzymania są, co prawda oddzielone przez ustawodawcę od zadań wykonywanych przez GOPR, niemniej $\mathrm{w}$ praktyce wymagają stałego monitorowania i utrzymania ich w należytym stanie, który nie będzie zagrażał bezpieczeństwu oraz zapewni pomoc ratowniczą dla narciarzy w sytuacji zagrożenia ich życia i zdrowia. Realizacja funkcji i zadań GOPR wspomaga zapobieganie zagrożeniom, a przez to wzmacnianiu bezpieczeństwa, które „jest pierwotną, egzystencjalną i naczelną wartością i potrzebą każdego człowieka, warunkującą przeżycie i rozwój jednostki i grup społecznych. W celu wzmocnienia poczucia bezpieczeństwa ludzie jednoczą się (stowarzyszają) oraz powołują państwo, jako najwyższą formę organizacyjną, gwarantującą bezpieczeństwo" (Skrabacz, 2006, s. 19).

Odnosi się to również bezpośrednio do kwestii związanych z łączeniem sił i środków pozwalających na zapobieganie zagrożeniom. Jako przykład można podać przedsięwzięcie „w ramach współpracy z Euroregionem TATRY z roku 2014, gdzie w ramach realizacji mikroprojektu ze środków unijnych z programu pt. Wzmocnienie działań $z$ dziedziny usług turystycznych i ochrony środowiska na pograniczu polsko-słowackim poprzez większa integrację i skuteczniejsze zapewnienie bezpieczeństwa przez służby porzadkowe i ratownicze został zakupiony pojazd 
terenowy typu quad wraz z zestawem GPS i goglami noktowizyjnymi” (Jedyna taka jednostka policji). Dzięki takiemu przedsięwzięciu zespoły poszukiwawcze mogą być monitorowane, ich pozycje przekazywane zdalnie do punktu dowodzenia, co pozwala osobie prowadzącej akcję ratowniczą na pełną kontrolę nad tym co dzieje się w terenie w rzeczywistym czasie. To także możliwość wykorzystania technologii mobilnych pozwalających na zdalne rozdzielanie zadań w terenie i ich modyfikację oraz komunikację między punktem dowodzenia i patrolami. Usprawnienia pojawiły się również w pracy przewodników psów, którzy zostali wyposażeni w urządzenia lokalizujące i zapisujące pracę ich psów w terenie. Taka inwestycja bardzo ułatwia czynności ratownicze i dowodzenie nimi. Warto w tym miejscu przypomnieć, że ratownictwo (w dziedzinie bezpieczeństwa powszechnego) definiowane jest jako „działalność prowadzoną na wszelkich szczeblach organizacji państwa w czasie pokoju, kryzysu i wojny, za pomocą różnych metod, sił i środków, w celu ratowania zdrowia i życia ludzkiego oraz (lub) dóbr materialnych" (Jedyna taka...), a ze względu na specyfikę środowiska, w jakim prowadzone są działania ratownicze, wyróżniamy ratownictwo: górskie, wodne, jaskiniowe, wysokościowe, drogowe oraz powodziowe (Skrabacz, 2004, s. 121). Można więc stwierdzić, że nie tylko samo ratownictwo, ale i związane z nim działania o charakterze zapobiegawcze stanowią całość, której nie można rozdzielać.

Druga sfera dotycząca zapobiegania zagrożeniom odnosi się raczej do ich zapobiegania przez edukację do bezpieczeństwa. Edukacja do bezpieczeństwa wspiera działania związane $\mathrm{z}$ zapobieganiem zagrożeniom $\mathrm{w}$ kilku warstwach, takich jak wiedza o bezpieczeństwie w kontakcie $\mathrm{z}$ naturą, zapobieganie wypadkom i niekorzystnym zdarzeniom oraz sposoby komunikowania się w sytuacji zagrożenia na trasach górskich, szacunek dla przyrody i jej poszanowanie, pierwsza pomoc itp. To ważny aspekt działań o charakterze zapobiegawczym, zwłaszcza w odniesieniu do turystyki górskiej i uprawiania sportów w górach.

Trzecia sfera odnosi się do realizacji wytycznych zawartych w porozumieniach o współpracy w euroregionach i dotyczy zarówno pracy na rzecz rozwoju i bezpieczeństwa lokalnych społeczności w tych rejonach, jak i propagowania dobrych praktyk. Podpisywanie deklaracji, porozumień, umów o charakterze dwu- lub trójstronnym między organizacjami tego typu pozwala na działania zgodnie z przyjętymi procedurami. To szczególnie ważne w sytuacji zarówno udzielania pomocy, jak i jej finansowania, czy lokowania tych działań w przyjętych rozwiązaniach prawnych poszczególnych państw. Należy pamiętać, że działanie w strefie przygranicznej łączy się z wchodzeniem w skomplikowane 
systemy prawne, finansowe czy pomocowe, które w sytuacjach zagrożeń zdrowia i życia są konieczne, a wiedza o nich jest ważna zarówno w trakcie podejmowania działań ratowniczych, jak i później w trakcie wyjaśniania podejmowanych trudnych decyzji.

Współpraca GOPR tak w zakresie ratownictwa, jak i zapobiegania zagrożeniom $\mathrm{z}$ podobnymi podmiotami z terenu Słowacji i Czech odbywa się na podstawie uregulowań prawnych poszczególnych państw oraz uregulowań między państwami graniczącymi ze sobą, w tym wypadku są to osobne porozumienia polsko-słowackie i polsko-czeskie.

Najważniejszym celem statutowym GOPR jest niesienie pomocy ofiarom wypadków w górach oraz poszukiwanie osób zaginionych w górach. Wyznaczone cele są realizowane poprzez organizowanie i prowadzenie służby ratowniczej oraz prowadzenie działalności zapobiegawczej. W wymiarze ratownictwa ratownicy GOPR ratują życie innym, często narażając własne, udzielają pomocy uczestnikom górskich wędrówek, ratując w sytuacjach, gdzie inna pomoc byłaby niemożliwa. Specjalistyczne przygotowanie i sprzęt pozwalają na realizowanie tego głównego celu. Ratownicy prowadzą również instruktaże i szkolenia w zakresie udzielania pierwszej pomocy, przygotowania się do wyjścia w góry, radzenia sobie w sytuacjach trudnych i ekstremalnych, dobierania sprzętu turystycznego i narciarskiego - zapobiegają zagrożeniom, wykorzystując możliwości edukacji do bezpieczeństwa.

Możliwości działania GOPR w zapobieganiu zagrożeniom są więc stosunkowo duże, na co wpływa zarówno doświadczenie zdobywane przez wiele dekad, jak i specjalistyczne przygotowanie, powiązane ściśle $\mathrm{z}$ ideą niesienia bezinteresownej pomocy. Ponadto GOPR, przynależąc do grupy organizacji pozarządowych, nie ogranicza się wyłącznie do działań w trzecim sektorze, ale sięga znacznie szerzej, przyczyniając się do dobrobytu społeczeństwa (Moroń, 2012, s. 11).

Dodatkowo można stwierdzić, że GOPR - mimo znaczącej roli w zapobieganiu zagrożeniom - jest organizacją w sposób mało znaczący opisaną w literaturze dotyczącej zarówno organizacji non profit, jak i współpracy transgranicznej realizowanej między innymi w formie euroregionów. To temat wart podjęcia jako nowe pole badawcze oraz w szerszej analizie współpracy transgranicznej w obrębie zapewnienia bezpieczeństwa. 


\section{WNIOSKI}

Podsumowując przedstawiony tekst, należałoby zwrócić uwagę na to, że GOPR jest jedną z grup dyspozycyjnych w procesie zapobiegania zagrożeniom w rejonach transgranicznych. Specyfika GOPR w zapobieganiu zagrożeniom polega na kilku sferach działalności. Do podstawowych należałoby zaliczyć działania, takie jak: 1. w zakresie niesienia pomocy w sytuacji zagrożenia lawinowego czy katastrof wymagających udziału tej specjalistycznej grupy; 2. działania związane $\mathrm{z}$ ratowaniem życia i zdrowia osób przebywających na terenach górskich, a zwłaszcza turystów i narciarzy; 3. to również cała sfera edukacyjna związana $\mathrm{z}$ wyposażeniem $\mathrm{w}$ wiedzę $\mathrm{z}$ zakresu bezpieczeństwa poruszania się po terenach górskich, kontaktu z przyrodą i bezpiecznych zachowań oraz radzenia sobie w sytuacjach trudnych w górach; 4 . współdziałanie z innymi służbami w operacjach o charakterze ratowniczym.

Ponadto GOPR w Strategii Bezpieczeństwa Państwa pełni ważną rolę w sferze obronnej, ochronnej, społecznej i gospodarczej, chociaż mało jeszcze docenianą i opisaną. Stąd istnieje istotna potrzeba objęcia badaniami tych grup, których wyniki mogłyby być ważnym elementem oceny ich działania i możliwości wykorzystania ich potencjału w systemie obronności kraju oraz w sytuacjach kryzysowych.

Wyzwania cywilizacyjne niosą ze sobą nowe zagrożenia wymagające nowej wiedzy, która pozwoli na jej wykorzystanie w warunkach i sytuacjach trudnych, wymagających działania innowacyjnego. Stąd istnieje potrzeba ciągłego wspomagania tej grupy poprzez szkolenia i dofinansowanie.

\section{BiBLIOGRAFIA:}

Bankowicz, M. (red.). (1999). Słownik polityki. Warszawa: Wydawnictwo Wiedza Powszechna.

Euroregiony $w$ Polsce. (2016). Pobrane z: www.karpacki.pl/euroregion-karpacki/euroregiony-w-/.

Jarmoszko, S. (2006). Dyspozycyjność wojskowych - Status quo czy zmiana. W: J. Maciejewski (red.), Grupy dyspozycyjne społeczeństwa polskiego. Wrocław: Wydawnictwo Uniwersytetu Wrocławskiego.

Jedyna taka jednostka policji. (2016). Pobrane z: www.krknews.pl/jedyna-grupaposzukiwawcza-policji-dziala-w-malopolsce/.

Komórki organizacyjne Ministerstwa wspótpracujące z organizacjami pozarządowymi. (2016). Pobrane z: https://mswia.gov.pl/pl/bezpieczenstwo/organizacje-pozarzadow/komorki-organizacyjne. 
Maciejewski, J. (2010). Wstęp. W: J. Maciejewski, M. Bodziany, K. Dojwa (red.), Grupy dyspozycyjne w obliczu wielkiej zmiany. Kulturowe i społeczne aspekty funkcjonowania $w$ świetle procesów integracyjnych. Wrocław: Wydawnictwo Uniwersytetu Wrocławskiego.

Maciejewski, J. (2014). Grupy dyspozycyjne. Analiza socjologiczna. Wrocław: Wydawnictwo Uniwersytetu Wrocławskiego.

Mazur, J. (2014). Trudny respondent w badaniach sondażowych grup dyspozycyjnych na przykładzie badań rzeczników prasowych policji. W: J. Maciejewski, M. Stochmal (red.), Metodologiczne problemy w badaniach grup dyspozycyjnych. Wrocław: Wydawnictwo Uniwersytetu Wrocławskiego.

Mazur, J. (2016). Bezpieczeństwo elastyczne jako refleksja naukowa poszukująca odpowiedzi na współczesne zagrożenia. Przedsiębiorczość i Zarządzanie, t. 17, z. 5.

Morawski, Z. (1999). Funkcjonowanie policji w strukturze społecznej. Wrocław: Wydawnictwo Uniwersytetu Wrocławskiego.

Moroń, D. (2012). Organizacje pozarządowe - fundament społeczeństwa obywatelskiego. Wrocław: Wydawnictwo Uniwersytetu Wrocławskiego.

Mrozowicz, K. (2013). Czynnik ludzki w górskim pogotowiu ratunkowym. Analiza osobowościowych uwarunkowań zachowań organizacyjnych ratowników górskich. Jarosław: Wydawnictwo Państwowej Wyższej Szkoły Techniczno-Ekonomicznej w Jarosławiu.

Nadzór nad Ratownictwem Górskim i Wodnym. (2016). Pobrane z: https://mswia.gov. $\mathrm{pl} / \mathrm{pl} /$ bezpieczenstwo/nadzor-nad-ratownictwe.

Olechnicki, K., Załęcki, P. (1997). Słownik socjologiczny. Toruń: Grafitti BC.

Organizacje posiadajace status OPP. (2016). Pobrane z: www.pozytek.gov.pl/Wykaz,organizacji,majacych,status,OPP,1020.html.

Ratownicy górscy Polski, Czech i Słowacji chcą ściślej współpracować. (2016). Pobrane z: www.gazetakrakowska.pl/artykul/933920,ratownicy-gorscy-polski-czech-islowacji-chca-scislej-wspolpracowac,id,t.html.

Rozporządzenie Ministra Spraw Wewnętrznych z dnia 29 grudnia 2011 roku w sprawie określenia wzorów znaków nakazu, zakazu, informacyjnych i ostrzegawczych stosowanych do oznakowania w górach i na zorganizowanych terenach narciarskich (Dz.U. Nr 295, poz. 1751).

Rozporządzenie Ministra Spraw Wewnętrznych z dnia 19 stycznia 2012 roku w sprawie dopuszczalnego obciążenia narciarskiej trasy zjazdowej, sposobu jego obliczania oraz szczegółowych warunków oświetlenia zorganizowanych terenów narciarskich (Dz.U. z 2012 roku, poz. 102).

Rozporządzenie Ministra Spraw Wewnętrznych z dnia 29 grudnia 2011 roku w sprawie stopni trudności narciarskich tras zjazdowych, biegowych i nartostrad oraz sposobu ich oznaczenia (Dz.U. Nr 295, poz. 1752).

Rozporządzenie Ministra Spraw Wewnętrznych z dnia 22 grudnia 2011 roku w sprawie określenia stopni zagrożenia lawinowego oraz odpowiadających im zaleceń dla ruchu osób (Dz.U. Nr 299, poz. 1777). 
Sanetra-Półgrabi, S. (2015). Funkcjonowanie euroregionów na pograniczu południowym Polski. Studium porównawcze euroregionów „Ślask Cieszyński”, „Beskidy”, „Tatry”. Toruń: Wydawnictwo Adam Marszałek.

Schmidt, J. (2012). Rozwój organizacji pozarządowych. Teoria i praktyka. Warszawa: SEDNO Wydawnictwo Akademickie.

Skrabacz, A. (2004). Ratownictwo w III RP: ogólna charakterystyka. Warszawa: Wydawnictwo AON.

Skrabacz, A. (2006). Ochrona ludności w Polsce w XXI wieku: wyzwania, uwarunkowania, perspektywy. Tarnów: Wyd. Merkuriusz.

Strategia Bezpieczeństwa Narodowego Rzeczypospolitej Polskiej. Warszawa. (2014).

Ustawa z 26 kwietnia 2007 r. o zarządzaniu kryzysowym, Dz.U. 2007 nr 89 poz. 590 z późn. zm., Art. 2.

Ustawa z dnia 24 kwietnia 2003 r. o działalności pożytku publicznego i o wolontariacie (Dz.U. z 2010 r. Nr 234, poz. 1536 oraz z 2011 r. Nr 112, poz. 654, Nr 149, poz. 887 i Nr 205, poz. 1211). 